\title{
Physico-chemical characterization and antioxidant capacity of the colombian berry (Vaccinium meridionale Swartz) with a high-polyphenol content: potential effects in people with metabolic syndrome
}

\author{
Julián QUINTERO-QUIROZ', Yeisson GALVIS-PÉREZ², Santiago GALEANO-VÁSQUEZ², \\ Catalina MARÍN-ECHEVERRI², Claudia FRANCO-ESCOBAR², Gelmy CIRO-GÓMEZ1, \\ Vitelbina NÚÑEZ-RANGEL ${ }^{3}$, Juan C. ARISTIZÁBAL-RIVERA ${ }^{4}$, Jacqueline BARONA-ACEVEDO ${ }^{3 *}$
}

\begin{abstract}
Colombian berry (agraz) has demonstrated a high antioxidant content in vitro. In the present study, it was elaborated and characterized an agraz nectar, designed a placebo with similar physicochemical and sensorial characteristics of the agraz nectar, but without polyphenols; and evaluated their antioxidant capacity both in vitro and in vivo in adults with cardiovascular risk factors. The polyphenolic concentration of the agraz nectar and its antioxidant capacity was superior than other reported for this fruit. A high content of total cyanidins was observed in the freeze-dried agraz, but not delphinin was detected by HPLC. For the intervention study, sixty-six subjects, with at least three cardiometabolic risk factors, consumed agraz nectar or placebo daily during 4 weeks each, separated by a 4-week washout period. Total phenol concentration and antioxidant capacity in the participants' serum were not statistically different after consuming agraz nectar and placebo. However, women increased significantly their serum DPPH scavenging capacity after consuming agraz nectar, compared to placebo. This is one of the first studies showing data about the effects of this colombian berry on the antioxidant capacity in people with metabolic syndrome.
\end{abstract}

Keywords: agraz; Vaccinium meridionale; antioxidant capacity; humans; metabolic syndrome.

Practical Application: antioxidant potential of this colombian fruit in human health.

\section{Introduction}

Blueberries belong to the genus Vaccinium and comprise about 400 species (Camp, 1945). Vaccinium meridionale Swartz, known as "agraz" or "mortiño", is distributed in Venezuela, Colombia, Ecuador, Peru and Jamaica, and is located at the Andean (Escobar et al., 2009). A total of 20 populations and 100 plants of V. meridionale Swartz (Ligarreto et al., 2011) have been individually characterized in Colombia. The $V$. meridionale fruits are globose berries of 5-10 mm diameter, with purple-dark color at maturity, with persistent calyx at the apex, edible pulp with some acid, but nice flavor, and contain numerous small seeds (Ávila et al., 2007).

Studies evaluating the polyphenol content of $V$. meridionale have demonstrated its antioxidant properties in vitro with similar or even higher potency than other Vaccinium reported (Gaviria et al., 2009; Montoya et al., 2009). Also, it was showed that $V$. meridionale berries are an excellent source of dietary phytochemicals such as anthocyanins and polyphenolics, being comparable to V. myrtillus (Garzón et al., 2010) which is known by its nutraceutical properties including management of visual disorders and protection against cancer, age-related neurodegenerative conditions, and inflammatory responses
(Zhao et al., 2004; Bao et al., 2008; Yao et al., 2010). A more recent study reported for the first time that a non-alcoholic extract of this colombian blueberry ( $V$. meridionale) exhibited cardioprotective effects against ischemia and reperfusion injury in isolated rat hearts (Lopera et al., 2013). Thus, V. meridionale is considered as a promissory fruit and a functional food for its high antioxidant content in vitro (Garzón et al., 2010) and although it has been included in the list of fruits with potential international market (Ligarreto, 2009), there is limited scientific information about the beneficial effects of the consumption of this colombian berry in humans.

People with metabolic syndrome (MetS), a group of interrelated risk factors, are at high risk of developing type 2 diabetes and cardiovascular disease (Grundy et al., 2005). It has been demonstrated that abdominal obesity, elevated blood pressure, impaired glucose tolerance, dyslipidemia, elevated oxidative stress, and inflammation, which are the prominent features of MetS, can be effectively modified with dietary interventions involving polyphenol-rich foods and beverages such as berries (Basu \& Lyons, 2012; Lopera et al., 2013; Nile $\&$ Park, 2014). Studies have demonstrated that consumption of

${ }^{1}$ Linea de Alternativas Terapéuticas y Alimentarias, Programa de Ofidismo, Facultad de Ciencias Farmacéuticas y Alimentarias, Universidad de Antioquia - UdeA, Medellín, Colombia

${ }^{2}$ Línea de Alternativas Terapéuticas y Alimentarias, Programa de Ofidismo, Universidad de Antioquia - UdeA, Medellín, Colombia

${ }^{3}$ Línea de Alternativas Terapéuticas y Alimentarias, Programa de Ofidismo, Escuela de Microbiología, Universidad de Antioquia - UdeA, Medellín, Colombia

${ }^{4}$ Grupo PHYSIS, Escuela de Nutrición y Dietética, Universidad de Antioquia - UdeA, Medellín, Colombia

*Corresponding author: maria.barona@udea.edu.co 
Vaccinium species is associated with a reduction in blood sugar levels (Grace et al., 2009), blood pressure (Basu et al., 2010) and low-density lipoprotein (LDL) oxidation (Basu et al., 2011; Shen et al., 2018). In addition, it was observed that after eating $V$. myrtillus L. resulted in significant increases in serum/plasma antioxidant capacity and this was associated to the activity of antioxidants present in this fruit, which may slow free-radical processes (Prior et al., 2007; Harasym \& Oledzki, 2014). Thus, increases in this marker, which may be measured by different methods, could be associated to some beneficial effects of Vaccinium fruit consumption.

In fact, studies have demonstrated increases in plasma antioxidant capacity and improvements in cardiometabolic risk factors after berries consumption or its anthocyanins (Basu et al., 2011; Kuntz et al., 2014; Shen et al., 2018). However, there is limited information about the effects of $V$. meridionale consumption on serum antioxidant capacity in people with MetS. In this study, we characterized a freeze-dried and reconstituted nectar from agraz, designed a placebo and evaluated the antioxidant capacity both in vitro and in vivo in people at high risk of cardiovascular disease.

\section{Materials and methods}

\subsection{Colombian freeze-dried berry / agraz preparation}

Agraz fruits were obtained in the east of Antioquia (Colombia). Fruits between $0.5 \pm 0.1 \mathrm{~g}$ of weight, soluble solids concentration of $13.9 \pm 1.8^{\circ} \mathrm{Brix}, \mathrm{pH}$ of $2.4 \pm 0.3$ and percentage of humidity of $80.0 \pm 4.2 \%$ were selected. Selected fruits were washed and disinfected with citrosan at $30 \%(\mathrm{v} / \mathrm{v})$ for $10 \mathrm{~min}$. and blanched in boiling water for 5 min (Nurhuda et al., 2013).

The elaboration of the lyophilized agraz was made at the Pilot Plant of the Food Department of the University of Antioquia. The scalded fruit was processed with an industrial blender, then it was pressed to separate the extract No. 1 from the solid residues (cake). The cake was mixed again with water to extract the greatest amount of poliphenolic compounds, and a second pressing was done to obtain the extract No. 2 from the solids of this cake. Both extracts (No. 1 and 2) were mixed with a maximum of $7^{\circ}$ Brix, to avoid extract caramelization during the freeze-drying process.

The lyophilization process of the extract was done at $0.427 \pm 0.5 \mathrm{~mm} \mathrm{Hg}$, temperature of $-50{ }^{\circ} \mathrm{C}$, and it was stored at $-18 \pm 2{ }^{\circ} \mathrm{C}$ protected from light (Figure 1). The freeze-dried (lyophilized) product of agraz was stored in refrigeration until use. The nectar of agraz provided for consumption in this study was prepared from the lyophilized product, $7.38 \mathrm{~g}$ were reconstituted in $200 \mathrm{~mL}$ of water to provide a daily dose equivalent to the phenols present in $200 \mathrm{~g}$ of fresh agraz fruits. The selection of this daily dose was based on beneficial effects observed in people with metabolic syndrome after consuming a polyphenol-rich beverage from grapes, using a similar protocol as this intervention (Barona et al., 2012).

\subsection{Placebo design}

The placebo was designed to match the sensorial and physicochemical characteristics and the calories contribution of $200 \mathrm{~mL}$ of agraz nectar, but without the poliphenolic compounds. The following food-grade ingredients were used to prepare $200 \mathrm{~mL}$ of placebo: carboxymethylcellulose, green food coloring, red mulberry food coloring, fructose, citric acid, and agraz flavoring. This last was design by Casa del Sur S.A.S.

\subsection{Microbiologic and physicochemical characterization of the agraz nectar and placebo}

The following parameters were analyzed to the freeze-dried and reconstituted agraz nectar, and the placebo: humidity, total protein, fat, ashes, $\mathrm{pH}$, soluble solids, and titratable acidity.

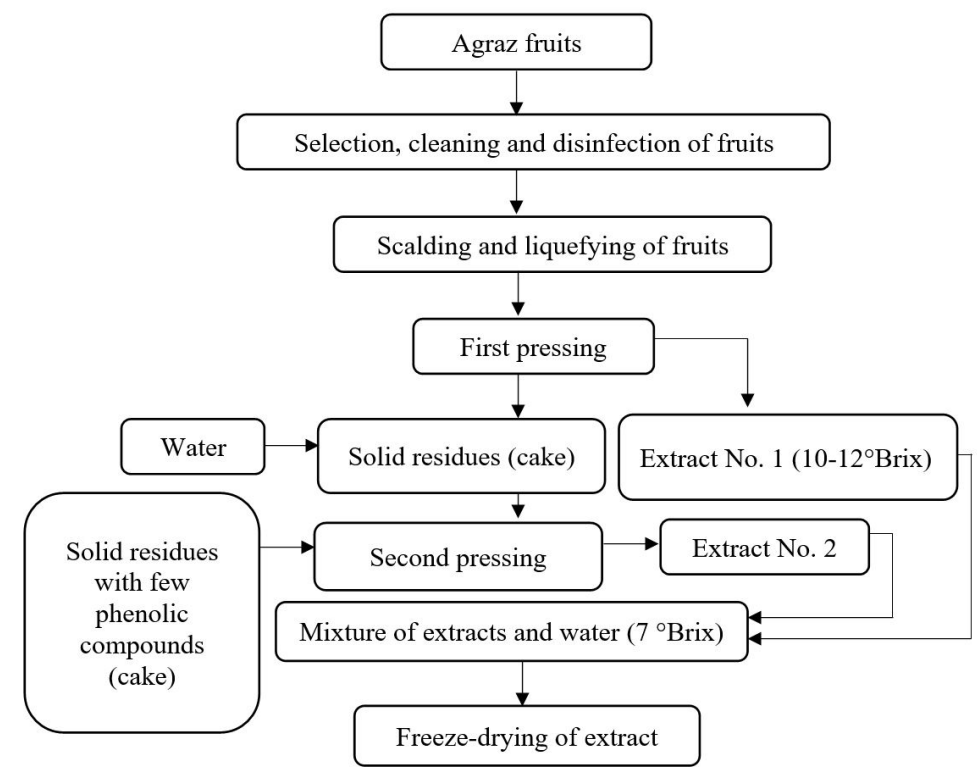

Figure 1. Process of obtaining the nectar of agraz with high content of polyphenols. 
The methodologies used were recommended by AOAC (Association of Official Analytical Chemistry) (Horwitz et al., 1990).

The viscosity was measured with a needle viscometer (BROOKFIELD RV) and the color of the nectar and placebo samples was analyzed with a portable spectrophotometer (X-RITE model SP62, light D65, observer of $10^{\circ}$ ); it was obtained the following color parameters: luminosity $\left(\mathrm{L}^{*}\right)$, red-green color $\left(\mathrm{a}^{*}\right)$, yellow-blue color $\left(b^{\star}\right)$, chromaticity $\left(c^{\star}\right)$ and Hue angle $\left(h_{a b}\right)$.

For the microbiologic analysis of the agraz nectar and placebo, the colombian technical standard 4092 (Instituto Colombiano de Normas Técnicas y Certificación, 2009) was followed for the counting of aerobic mesophiles, moulds and yeasts and the determination of the most probable number (MPN) of fecal and total coliforms.

\subsection{Intervention in subjects with metabolic syndrome}

A double-blind study with a crossover design during 12 weeks (wk) was carried out, in which 66 subjects (40 women and 26 men, $46.6 \pm 10.4$ years) with MetS, according to the ATP-III definition (Grundy et al., 2005), were included. The volunteers were randomly assigned to consume either agraz nectar (prepared daily from freeze-dried agraz) or placebo for $4 \mathrm{wk}$. After a washout period of $4 \mathrm{wk}$, participants were switched to the alternative treatment. Participants registered daily consumption of nectar, and a weekly questionnaire to assess adherence to the study. During the whole study, including the washout period, volunteers were asked to refrain from consuming foods rich in polyphenols such as fruits (grapes and other berries), wine and tea or derived products. At the end of each intervention period, measurements and blood samples were collected.

\subsection{Ethical considerations}

The protocol of the intervention study was approved by the Human Bioethical Committee of the Sede de Investigación Universitaria, Universidad de Antioquia, according to the Act. No. 14-35-558 (for men) and 15-35-558-02 (for women). All participants firmed the informed consent format before entering the study. Participants' personal information was protected and not revealed.

\subsection{Blood collection}

Blood samples were collected from the antecubital vein using dry tubes after an overnight $12 \mathrm{~h}$ fast. After $30 \mathrm{~min}$, the tubes were centrifuged at $2000 \times \mathrm{g}$ for $10 \mathrm{~min}$ to obtain serum, which was aliquoted and frozen at $-80^{\circ} \mathrm{C}$ for further analysis.

\subsection{Serum deproteinization}

To remove protein interferences, the serum was deproteinized following the method by Serafini et al. (1998) with modifications. First, to separate the polyphenols from lipids, $300 \mu \mathrm{L}$ of $1.0 \mathrm{~mol} / \mathrm{L}$ $\mathrm{HCl}$ was added to $150 \mu \mathrm{L}$ of serum. This mix was vortexed for $60 \mathrm{~s}$ and incubated at $37^{\circ} \mathrm{C}$ for $30 \mathrm{~min}$. Then, $300 \mu \mathrm{L}$ of $2 \mathrm{~mol} / \mathrm{L}$ $\mathrm{NaOH}$ in $75 \%$ of methanol was added, vortexed for $3 \mathrm{~min}$ and incubated at $37{ }^{\circ} \mathrm{C}$ for $30 \mathrm{~min}$. After that, to precipitate de proteins, $300 \mu \mathrm{L}$ of $0.75 \mathrm{~mol} / \mathrm{L}$ metaphosphoric acid (MPA) was added, vortexed for $3 \mathrm{~min}$ and centrifuged at $1500 \times \mathrm{g}$ for $10 \mathrm{~min}$. The supernatant was removed and stored in refrigeration in darkness. In other vial, $300 \mu \mathrm{L}$ of a 1:1 (v/v) solution of acetone:water were added and centrifuged at $2700 \times \mathrm{g}$ for $10 \mathrm{~min}$. The two supernatants were combined and filtered through a HV $0.45-\mathrm{mm}$ filter. The filtered serum was immediately used to measure total phenols and 2,2-diphenyl-1- picryl-hydrazyl $(\mathrm{DPPH})$ scavenging activity.

\subsection{Total phenol concentration in agraz nectar, placebo and serum}

Total phenolic concentration in agraz, placebo and deproteinized serum was measured by the Folin-Ciocalteau method (Swain \& Hillis, 1959) modified to remove protein interferences (from serum) as previously described (Serafini et al., 1998). Twenty $\mu \mathrm{L}$ of sample or standard of gallic acid (GA) (standard curve of $0-1000 \mathrm{mg} / \mathrm{L}$ of GA) were diluted in $1580 \mu \mathrm{L}$ of distilled water. Then, $100 \mu \mathrm{L}$ of Folin-Ciocalteau reagent was added and mixed. After that, $300 \mu \mathrm{L}$ of $20 \%$ sodium carbonate were added and the color generated was read after $1 \mathrm{~h}$ at $725 \mathrm{~nm}$ in spectrophotometer (UV-1700, Shimadzu Europe ${ }^{\circledR}$ ). During processing, the samples were protected from light. The experiments were performed in triplicate and the results were expressed as $\mathrm{mg}$ of gallic acid equivalents per liter (mg GAE/L).

\subsection{ABTS assay in agraz nectar and placebo}

The ABTS assay was performed following the method described by Contreras-Calderón et al. (2011). $100 \mu \mathrm{L}$ of test sample (diluted appropriately with water) or Trolox ${ }^{\circledR}$ standard was mixed with $1 \mathrm{~mL}$ of $\mathrm{ABTS}^{+}$solution and incubated at $30^{\circ} \mathrm{C}$ for $30 \mathrm{~min}$. Absorbance readings at $730 \mathrm{~nm}$ were taken using a spectrophotometer (UV-1700, Shimadzu Europe ${ }^{\circledR}$ ). Aqueous solutions of Trolox ${ }^{\circledR}$, at concentrations between 0 and $500 \mu \mathrm{mol}$, were used for calibration. Results were expressed as $\mu \mathrm{mol}$ of Trolox $^{\circledR}$ equivalents per liter $(\mu \mathrm{mol} \mathrm{TE} / \mathrm{L})$.

\subsection{Ferric reducing ability of plasma/serum (FRAP) assay in agraz nectar, placebo and serum}

FRAP was measured as previously described by Benzie \& Strain (1996) with modifications. $90 \mathrm{~mL}$ of deionized water was mixed with $30 \mu \mathrm{L}$ of serum and added to $900 \mu \mathrm{L}$ of a FRAP reagent (pre-warmed at $37^{\circ} \mathrm{C}$ ). The serum was incubated by $10 \mathrm{~min}$ and nectar and placebo were incubated for $30 \mathrm{~min}$, respectively, at $37^{\circ} \mathrm{C}$. Then, the sample absorbance at $593 \mathrm{~nm}$ using a spectrophotometer (UV-1700, Shimadzu Europe $\left.{ }^{\circledR}\right)$ was obtained. A Trolox ${ }^{\circledR}$ calibration curve $(0-400 \mu \mathrm{mol}$ Trolox/L) was done for quantification purposes and the results were expressed as $\mu \mathrm{mol} \mathrm{TE} / \mathrm{L}$.

\subsection{DPPH assay in agraz nectar and placebo}

The DPPH assay was performed as previously described (Nurhuda et al., 2013). $2 \mathrm{~mL}$ of DPPH reagent $0.5 \mathrm{mmol}$ (containing $\mathrm{DPPH}$ and methanol) was mixed with $2 \mathrm{~mL}$ of methanol and $0.2 \mathrm{~mL}$ of diluted sample (dilution was performed as necessary 
to ensure DPPH was not consumed before 30 min of reaction). Maximum absorbance values at $517 \mathrm{~nm}$ were recorded after 30 min of incubation in darkness (UV-1700, Shimadzu Europe ${ }^{\circledR}$ ). Aqueous solution of Trolox ${ }^{\circledR}$ at concentrations between 0 and $2000 \mu \mathrm{mol}$ were used for calibration purposes. Results were expressed as $\mu \mathrm{mol} \mathrm{TE/L.}$

\subsection{Serum DPPH scavenging activity}

DPPH scavenging activity was measured using a modification of the method described by Chrzczanowicz et al. (2008). Briefly, $5 \mu \mathrm{L}$ of $10 \mathrm{mmol} / \mathrm{L}$ of DPPH radical in methanol was mixed with $970 \mu \mathrm{L}$ of methanol. Then, $25 \mu \mathrm{L}$ of deproteinized serum with metaphosphoric acid or $25 \mu \mathrm{L}$ of the control (mix of the reagent to deproteinize without serum) was added, mixed and incubated by $30 \mathrm{~min}$ in dark. Finally, the decrease in the absorbance related to the DPPH radical decomposition in the samples and control was read at $517 \mathrm{~nm}$ using a spectrophotometer (UV-1700, Shimadzu Europe $\left.{ }^{\circledR}\right)$. All experiments were performed in triplicate and the scavenging effect (Sc\%) of DPPH was calculated using the following formula: Sc\% $=(1-($ A517 serum sample $/$ A517 control) $) \times 100$.

\subsection{ORAC assay in the freeze-dried agraz and placebo}

The antioxidant capacity of the freeze-dried agraz and placebo was measured by the ORAC (Oxygen Radical Absorbance Capacity) method, following procedure as described previously by Ou et al. (2001) 2,2'-Azobis-(2-amidinopropane)-dihydrochloride (AAPH) was used as the peroxyl radical generator, Trolox as the standard and fluorescein as the fluorescent probe. Fluorescein, AAPH and samples were prepared in $75 \mathrm{mmol}$ buffer at $\mathrm{pH}$ 7.4. Samples $(3 \mathrm{mg} / \mathrm{mL})$ or Trolox standards $(25 \mu \mathrm{L})$ were mixed with $150 \mu \mathrm{L}$ of $1 \mu \mathrm{mol} / \mathrm{L}$ fluorescein and pre-incubated at $37^{\circ} \mathrm{C}$ for 30 min before addition of $25 \mu \mathrm{L}$ of AAPH solution $(200 \mathrm{mmol} / \mathrm{L})$. The fluorescence at an excitation wavelength of $485 \mathrm{~nm}$ and an emission wavelength of $520 \mathrm{~nm}$ was measured every 2 min for 120 min using a Spectra Max Gemini EM (Molecular Devices, Orleans Dr, Sunnyvale, CA, USA). A calibration curve with Trolox $(12.5-100 \mu \mathrm{mol} / \mathrm{L})$ was performed for quantification purposes. The results are expressed as $\mu \mathrm{mol} \mathrm{TE} / \mathrm{g}$ of sample (Bravo et al., 2015).

\subsection{Anthocyanin determination by HPLC (High performance liquid chromatography).}

Freeze-dried agraz was analyzed using HPLC-DAD (diode array detection). The quantification of cyanidin and delphinidin and their glycosides was made by using the calibration curve of cyanidin and delphinidin standards (see complementary material). Anthocyanins in the freeze-dried agraz was reported as mg of cyanidin/delphinidin equivalents. These compounds are the most frequently reported for this fruit (Garzón et al., 2010).

\subsection{Statistical Analysis}

Results are presented as mean and standard deviation (SD), median and interquartile range, according to normality of data. The distribution of data was assessed by the KolmogorovSmirnov test with Lilliefors correction. A paired samples t-test was conducted to analyze differences between the agraz and placebo consumption periods. To analyze differences in the physico-chemical characteristics between the freeze-dried agraz, nectar and placebo, it was used multiple range test. Differences with a $p<0.05$ were considered significant. Analyses were done using Statgraphics centurion XVI and SPSS version 21 for Windows, 2012.

\section{Results and discussion}

Fruits belonging to $V$. meriodionale have generated interest for their potential health benefits related to their high concentration of polyphenols with demonstrated antioxidant properties in vitro (Garzón et al., 2010).

Among the challenges the food industry has, it is to take advantage of the potentialities present in the fresh fruit and transform it into a product that potentialize and keep the natural bioactive properties of the primary source. During the process of fruit transformation, there is degradation of bioactive compounds and loss of the fruit natural color, due to the endogenous polyphenol oxidase (PPO) enzyme (Skrede et al., 2000), which oxidizes polyphenolic compounds to quinones -brown-colored substances (Lee et al., 2002). In this study, it was applied a thermic treatment to the agraz fruit, as an alternative to decrease its PPO activity. For this, the agraz fruits were submerged into hot water $\left(80^{\circ} \mathrm{C}\right)$ during $5 \mathrm{~min}$ (Figure 1$)$. This process also allows polyphenols extraction from the skin of the fruit (Lee et al., 2002). However, one step of extraction was insufficient due to solvent (water) saturation. To guarantee a product with high concentration of polyphenolics, a second extraction step was performed to the presscake obtained during the first extraction.

Previous studies with blueberries have found the solid residue after anthocyanins extraction contains 55.3 to $71.8 \mathrm{mg}$ of anthocyanins per $100 \mathrm{~g}$ of residue (Lee et al., 2002). These compounds can be easily extracted in a second stage of extraction. Finally, the filtrates obtained during the two steps of extraction were mixed until a $7^{\circ}$ Brix solution and adjusted to facilitate the lyophilization process. This freeze-drying process preserved the nectar for long periods of time, without losing its nutritious and sensorial characteristics (Zielinska et al., 2015). This preservation of the polyphenolic compounds present in the agraz nectar was important for the clinical study.

\subsection{Microbiological analysis of the blueberry-agraz and placebo}

The microbiological analysis of the freeze-dried and reconstituted agraz (nectar), and placebo showed they were innocuous. This was supported by the microbiological counts of $<1 \mathrm{UFC} / \mathrm{mL}$ for aerobic mesophylls and molds and yeasts, and negative of total and faecal coliforms by for the most probable numbers (MPN) when those products were analyzed. These results demonstrated that analyzed samples complied with the colombian standard technique (NTC, from the spanish: Norma Técnica Colombiana 4092) (Instituto Colombiano de Normas Técnicas y Certificación, 2009) and the products were safe for human consumption. 


\subsection{Physico-chemical characterization of the freeze-dried agraz and placebo.}

For the evaluation of the agraz consumption effects in people with metabolic syndrome, the freeze-dried agraz was reconstituted in $200 \mathrm{~mL}$ of drinking water to provide a phenolic compound concentration equivalent to $1,027.97 \pm 41.99 \mathrm{mg} \mathrm{GA}$ per L of agraz nectar.

Additionally, for the intervention study, it was also necessary to design a placebo with similar physicochemical and sensorial characteristics of the agraz nectar, but free of polyphenolics. The nectar color $\left(a^{*}, b^{*}, L, c^{*}, h\right)$ and its rheological behavior (viscosity) determined the sensorial parameters perceived by the final consumer, such as the sensation in the mouth and visual appearance (Vahos et al., 2016). For this, it was used different food additives providing similar calories as the agraz nectar, but without polyphenol contribution.

The sensorial and physicochemical characteristics of the freeze-dried agraz, nectar and placebo are shown in Table 1. The freeze-dried product of agraz with high polyphenol content had the following physicochemical composition: $14.65 \pm 0.13 \%$ humidity, $1.39 \pm 0.25 \%$ protein, $3.48 \pm 0.24 \%$ ether extract, $1.62 \pm 0.03 \%$ ashes and $78.85 \pm 0.19 \%$ carbohydrates. Additionally, the polyphenolic compound composition was $139.29 \pm 5.69 \mathrm{mg}$ of GA per $g$ of freeze-dried product of agraz. These results differ from other reported by Tobón et al., (2016), who characterized physicochemically a freeze-dried product of agraz and reported the following composition: $5.28 \pm 0,01 \%$ humidity, $4.70 \pm 1,09 \%$ protein, $1.44 \pm 0.18 \%$ ether extract, $1.75 \pm 0.01$ ashes, and a concentration of polyphenolic compounds of $12.00 \mathrm{mg} \mathrm{GAE} / \mathrm{g}$ of product. This last result is 12 times lower than the concentration of phenolics reported in the present study. This might be explained by the thermic treatment to which the agraz fruit underwent to deactivate the endogenous enzymes that degrade polyphenolic compounds; and to the two stages of polyphenolic extraction applied in the process.

For the intervention, the physicochemical composition of the agraz nectar dose supplied daily for each volunteer is presented in Table 1.

The statistical analysis of the physicochemical properties (humidity, ether extract, titratable acidity, $\mathrm{pH}$, carbohydrates, density and calories per dose) between the nectar and placebo showed no statistical differences $(p>0.05)$. Regarding the sensorial parameters of nectar and placebo, both samples had similar rheological behavior $(\mathrm{p}>0.05)$. Thus, the agraz nectar viscosity $(\mu)$ varies with the revolutions per minute $(N)$ of viscometer according to the following mathematical relation: $\mu=0.0717 \mathrm{~N} \pm 6.03 \mathrm{cP}$, which is comparable to the placebo behavior $(\mu=0.0598 \mathrm{~N} \pm 6.51 \mathrm{cP})$. Similarly, the color parameters did not differ between the nectar and placebo (luminosity: $11.39 \pm 0.1$ and $11.12 \pm 0.01$, respectively).

On the other hand, the placebo was statistically different from the agraz nectar $(\mathrm{p}<0.05)$ in the polyphenolic compound concentration $(31.91 \pm 3.15 \mathrm{mg}$ GAE/L vs. $1,027.97 \pm 41.99 \mathrm{mg}$ GAE/L, respectively) and the antioxidant capacity measured by

Table 1. Physicochemical and nutritious properties of the freeze-dried agraz, nectar and placebo.

\begin{tabular}{|c|c|c|c|}
\hline \multirow[b]{2}{*}{ Physicochemical analysis } & \multirow[b]{2}{*}{ Freeze-dried agraz } & Nectar & \multirow{2}{*}{$\begin{array}{c}\text { Placebo } \\
(200 \mathrm{~mL})\end{array}$} \\
\hline & & $\begin{array}{c}\text { (reconstituted from } \\
\text { freeze-dried agraz in } 200 \mathrm{~mL} \text { ) }\end{array}$ & \\
\hline Humidity (\%) & $14.65 \pm 0.13^{\mathrm{a}}$ & $97.00 \pm 0.23^{\mathrm{b}}$ & $97.47 \pm 0.21^{\mathrm{b}}$ \\
\hline Ether extract (\%) & $3.48 \pm 0.24^{\mathrm{a}}$ & $0.12 \pm 0.01^{\mathrm{b}}$ & $0.01 \pm 0.21^{\mathrm{b}}$ \\
\hline Ashes (\%) & $1.62 \pm 0.03^{\mathrm{a}}$ & $0.06 \pm 0.01^{\mathrm{b}}$ & $0.18 \pm 0.03^{c}$ \\
\hline Carbohydrates (\%) & $78.85 \pm 0.19^{\mathrm{a}}$ & $2.08 \pm 0.19^{\mathrm{b}}$ & $2.50 \pm 0.19^{b}$ \\
\hline Density $(\mathrm{g} / \mathrm{mL})$ & 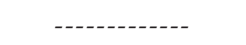 & $0.999 \pm 0.010^{\mathrm{a}}$ & $0.998 \pm 0.01^{\mathrm{a}}$ \\
\hline Calories per dose (Kcal) & 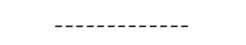 & $26.00 \pm 0.18^{\mathrm{a}}$ & $21.86 \pm 0.21^{\mathrm{a}}$ \\
\hline Rheological behavior* & 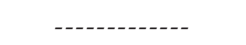 & $\mu=0.07 \mathrm{~N} \pm 6.03^{\mathrm{a}}$ & $\mu=0.06 \mathrm{~N} \pm 6.51^{\mathrm{a}}$ \\
\hline Total phenols (mg GAE/g of freeze-dried or L) & $139.29 \pm 5.69^{\mathrm{a}}$ & $1,027.97 \pm 41.99^{\mathrm{b}}$ & $31.91 \pm 3.15^{c}$ \\
\hline \multicolumn{4}{|c|}{ Color parameters } \\
\hline hab & 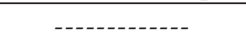 & $4.66 \pm 0.12^{\mathrm{a}}$ & $5.73 \pm 0.08^{\mathrm{a}}$ \\
\hline$a^{*}$ & ------------ & $5.86 \pm 0.03^{\mathrm{a}}$ & $5.85 \pm 0.17^{\mathrm{a}}$ \\
\hline$b^{*}$ & -----o---- & $0.50 \pm 0.01^{\mathrm{a}}$ & $0.64 \pm 0.02^{\mathrm{a}}$ \\
\hline$c^{*}$ & 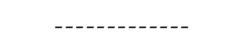 & $5.89 \pm 0.09^{\mathrm{a}}$ & $6.09 \pm 0.17^{\mathrm{a}}$ \\
\hline $\mathrm{L}$ & ------------ & $11.39 \pm 0.11^{\mathrm{a}}$ & $11.12 \pm 0.01^{\mathrm{a}}$ \\
\hline
\end{tabular}

${ }^{\star}$ Rheological behavior refers to: $\mu$, viscosity $(\mathrm{cP})$, N: velocity of agitation $(\mathrm{rpm})$. Luminosity $\left(\mathrm{L}^{*}\right)$, red-green color $\left(\mathrm{a}^{\star}\right)$, yellow-blue color $\left(\mathrm{b}^{\star}\right)$, chromaticity $\left(\mathrm{c}^{\star}\right)$, Hue angle $\left(\mathrm{h}_{\mathrm{ab}}\right)$. Different superscript letters for freeze-dried, nectar and placebo indicate significant differences $(p<0.05)$ according to Tukey's test. GAE: Gallic Acid Equivalents; TE: Trolox Equivalents. 
DPPH, FRAP, ABTS and ORAC. Thus, the placebo achieved its goal, being a drink without significant antioxidant activity, but with similar sensorial characteristics as the agraz nectar. In fact, most of the participants did not recognize sensorial differences between the two beverages given in a blinded way.

The highest antioxidant capacity for the agraz nectar was found using the ORAC method, followed by FRAP, ABTS and DPPH (Table 1). As reported by others, the large difference found by ORAC, FRAP and ABTS may be indicative of the compounds present in blueberries that act stronger as a scavenger of peroxyl radicals than as donors of electrons to the $\mathrm{Fe}^{3+}$ or $\mathrm{ABTS}^{+}$radical cation (Pertuzatti et al., 2014).

The antioxidant capacity of the freeze-dried agraz by the ORAC method was superior $(63,717 \pm 13.03 \mu \mathrm{mol} \mathrm{TE} / 100 \mathrm{~g}$ freeze-dried $)$ than the reported $(41,775.2 \pm 6,168.2 \mu \mathrm{mol} \mathrm{TE} / 100 \mathrm{~g}$ lyophilized) by Maldonado-Celis et al. (2014) for the same fruit, which could be attributed to the thermic treatment applied to the agraz fruits, as it has been suggested previously, the thermic treatments favor the extraction of polyphenols present in the agraz fruits with the subsequent increase in their antioxidant capacity (Vahos et al., 2016). Regarding the ORAC value found for the freeze-dried agraz $(637.17 \mu \mathrm{mol} \mathrm{TE} / \mathrm{g})$, this value is in the range reported by Pertuzatti et al. (2014) for 10 cultivars of the Brazilian V. corymbosum L. and V. ashei Reade (533-1,028 $\mu \mathrm{mol} \mathrm{TE/g} \mathrm{of} \mathrm{dry} \mathrm{weight).}$

The ABTS method measures the capacity of the antioxidant to react with the ABTS+ radical (probably through electron transfer), while the FRAP assay measures the potential of an antioxidant to reduce the yellow-TPTZ ferric complex to a ferrous-TPTZ blue complex by electron donors in acidic conditions. Our results demonstrated the agraz nectar did not lose its in vitro capacity to donate electrons, with the ability to reduce the radical ABTS+ and reduce the ferric complex to a ferrous complex (Garzón et al., 2010).

\subsection{Anthocyanin determination by HPLC-DAD in the freeze-dried agraz}

The HPLC analysis of the freeze-dried agraz showed a total cyanidin content of $4.66 \mathrm{mg}$ cyanidin equivalents/g, which is higher than other results previously reported [ $3.29 \mathrm{mg}$ cyanidin equivalents/g (Garzón et al., 2010) and $1.51 \mathrm{mg}$ cyanidin equivalents/g (Maldonado-Celis et al., 2014)]. Figure 2 shows 3 peaks, the peak of cyanidin (peak 3 ) and the peaks 1 and 2 correspond possibly to glucosides of cyanidin, which have been detected previously for this fruit using HPLC-MS with in-house protocol in which these peaks had a molecular ion value of $287.06 \mathrm{~m} / \mathrm{z}$ corresponding to glucosides of cyanidin according to the literature (Garzón et al., 2010). Garzón et al., 2010 reported delphinidin glucoside peaks when analyzing the agraz fruit. However, in the freeze-dried agraz analyzed in this study, there was not detection of delphinidin given the sample did not evidence a peak in the retention time (7.7 min) corresponding to delphinidin standard (Figure 2). It is important to mention that the diversity in the content of anthocyanins in agraz fruits, it could be explained by multiple factors such as environmental conditions where the fruit grows, ripeness of the fruit, and storage conditions (Gaviria et al., 2009), and the increase in the content of anthocyanins reported in this study, it may be due to the previous treatment of the fruit, as described before for the characterization of the nectar.

\subsection{Serum antioxidant capacity after consumption of agraz}

A high polyphenol content and in vitro antioxidant capacity for agraz fruits have been previously reported (Gaviria et al., 2012). In addition, a meta-analysis showed that berries consumption significantly reduced several risk factors of cardiovascular disease (Huang et al., 2016), and these effects have been attributed in part to the antioxidant activity of polyphenols present in the fruits (Pérez-Jiménez et al., 2010). Therefore, we hypothesized that agraz consumption would increase serum total phenols and serum antioxidant capacity in vivo.

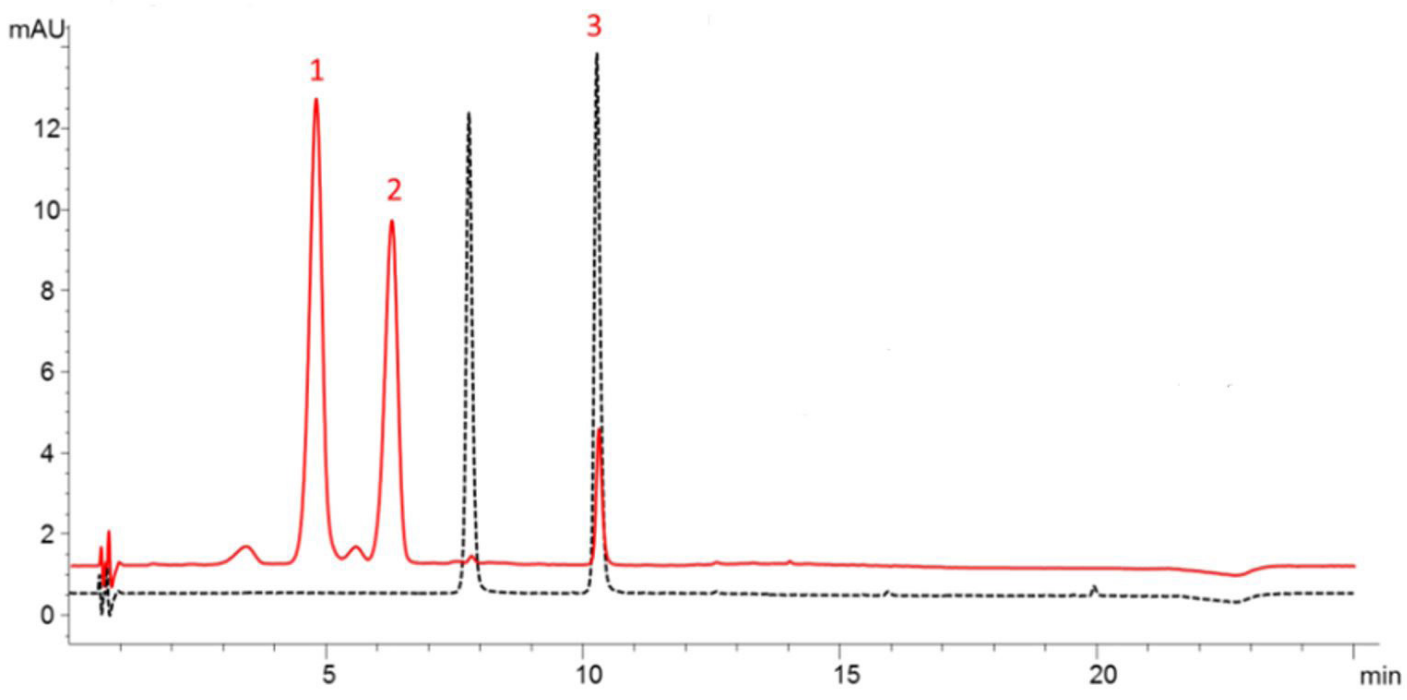

Figure 2. HPLC analysis of the freeze-dried agraz. Dotted line: Standards, Delphinidin (7.7 min), cyanidin (10.2 min). Red line. Peak 1: (4,8min) cyanidin glucoside 1, peak 2: (6.3 min) cyanidin glucoside 2, peak 3: (10.2 min) cyanidin. 


\section{Serum total phenols}

After blueberry-agraz nectar consumption, compared to placebo (263.8 mgGAE/L), the serum content of total phenols (280.2 mgGAE/L) increased by $6 \%$, although it was not significant $(\mathrm{p}=0.188$ ) (Figure 3 ). The same finding was reported by others evaluating blueberry juice supplementation in an acute study with 20 healthy female volunteers (Pedersen et a., 2000). Another acute study evaluating plasma antioxidant capacity after strawberries consumption, reported no increases in polyphenol levels. The authors stated that antioxidant activity may be confounded by selection of methods and time of blood sampling (Prymont-Przyminska et al., 2016). Volunteers in this study consumed the agraz nectar during 4 wk; thus, it was expected that with this chronic consumption the levels of polyphenols in serum and their antioxidant capacity would be higher, compared to the placebo period, regardless of time of blood sampling. Participants arrived for blood sampling after $12 \mathrm{~h}$ of overnight fast.

\section{Serum FRAP}

There were no statistical differences $(p=0.755)$ in the antioxidant capacity measured by FRAP between the agraz ( 654.8 $\mu \mathrm{molTE} / \mathrm{L})$ and placebo $(660.3 \mu \mathrm{molTE} / \mathrm{L})$ periods (Figure 3$)$. A similar result was found in a chronic intervention with cranberry, the antioxidant potential of the plasma measured by FRAP were unaffected by the intervention (Duthie et al., 2006). However, an acute intervention with cranberry juice showed a significant change in antioxidant capacity of plasma measured by the Fe3+ reduction (Pedersen et al., 2000). Interestingly, in the same study there were not significant increases in FRAP after acute blueberry juice consumption, which could be due to the composition of bioactive substances that varies from one fruit to another (Pedersen et al., 2000).

Serum DPPH. The DPPH radical scavenging capacity increased by $3.5 \%$ at the end of the agraz nectar consumption (17.7 Sc\%), compared to placebo (17.1 Sc\%), but this result was not statistically significant $(\mathrm{p}=0.227)$ in the whole group (Figure 3). However, when analyzing by sex, women increased their serum DPPH scavenging capacity by $19 \%(\mathrm{p}=0.045)$ after consuming agraz nectar (12.1 Sc\%), compared to placebo
(10.2 Sc\%). This result differs from other studies done in healthy populations (Alvarez et al., 2015), in which the authors reported lower values of DPPH scavenging capacity in women compared to men; although the type of population and fruit consumed are different from this study. Another study evaluating the acute effects of apple juice in 12 healthy volunteers found a significant increment in serum DPPH radical scavenging activity $1 \mathrm{~h}$ after consumption, after which the activity was reduced (Chrzczanowicz et al., 2008).

There are some aspects important to consider when analyzing the results of this study. First, the bioavailability of polyphenols, which is affected by the chemical structure of polyphenols and it determines the rate and extent of absorption and the nature of metabolites circulating in blood (D’ Archivio et al., 2007). Thus, blood concentrations after polyphenol consumption vary highly depending on the structure of the polyphenol and food source (Manach et al., 2004). The maintenance of a high concentration of polyphenols in plasma was shown to require repeated ingestion overtime (van het Hof et al., 1999). Some studies in which polyphenol metabolites were present at much higher concentrations in specific tissues than in blood, suggest that circulating levels of polyphenols are not directly correlated with concentrations in target tissues, which implies that plasma metabolite concentration of polyphenols may not be the most appropriate marker of exposure (Ferruzzi et al., 2009). Second, it is possible that the metabolites produced by the action of gut microbiota or by enzymatic conjugation in different tissues, such as intestine and liver (Santo-Buelga et al., 2010), could not have been detected by the methods used in this study, which have been standardized or used preferably to measure native polyphenol compounds or the antioxidant capacity of fruits or food matrices, but not in human blood samples. Third, the dose used in the present study was to simulate the habitual consumption of this type of fruits; thus, studies with higher doses, and more time of intervention are warranted. However, this is one of the first studies showing data about the effects of this colombian agraz ( $V$. meridionale Swartz) on the antioxidant capacity in people with metabolic syndrome, and about the potential of this fruit to be explore in human health conditions.

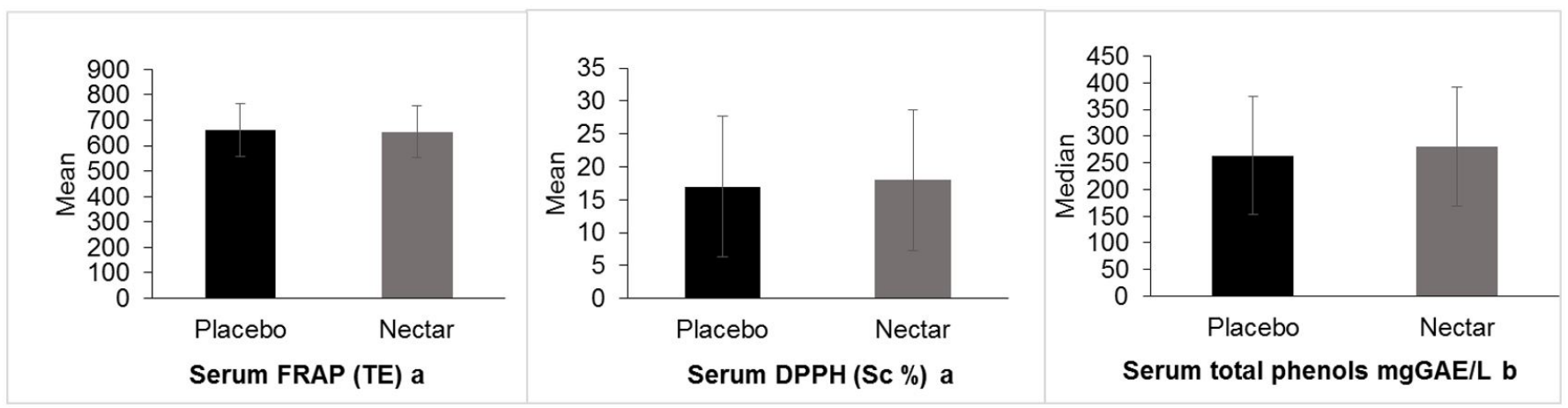

Figure 3. Total phenols and antioxidant capacity (measured by FRAP and DPPH) in serum after consumption of the colombian agraz nectar or placebo. FRAP, ferric-reducing antioxidant power; TE, Trolox equivalent ( $\mu$ mol TE/L sample); DPPH, 2,2'-diphenyl-1-picrylhydrazyl; Sc, scavenging effect; GAE, Gallic Acid Equivalents; a. T paired; b. Wilcoxon. 


\section{Conclusions}

The agraz nectar elaborated and characterized in this study showed a high polyphenolic content, which could be associated to the increase in participants' serum antioxidant capacity, measured by DPPH scavenging capacity, after consuming agraz nectar, compared to placebo. This is the first study showing initial data about the effects of this colombian berry on the antioxidant capacity in people at high risk for cardiovascular disease.

\section{Acknowledgement}

We thank the volunteers who participate in the intervention study. Also, to the Food Department of the Facultad de Ciencias Farmacéuticas y Alimentarias, Universidad de Antioquia UdeA, for allowing the preparation of the agraz nectar in the Food laboratory facilities. Funding Sources - This research was supported by the Comité para el Desarrollo de la InvestigaciónCODI - (Act No. 29, Junio de 2014) - Universidad de Antioquia UdeA, and Colciencias (Código No. 111565740563).

\section{References}

Alvarez, E., Rosa, L., García, R., Urquidez, R., Carrasco, K., Saénz, L., et al. (2015). Efecto del consumo de tres raciones de frutas minimamente procesadas al día en la capacidad antioxidante del plasma de donantes sanos (Disertación). Universidad Autónoma de Ciudad Juárez, Juárez, Chihuahua, México.

Ávila, H., Cuspoca, J., Fischer, G., Fischer, G., Ligarreto, G., \& Quincazán, M. (2007). Caracterización fisicoquímica y organoléptica del fruto de agraz (vaccinium meridionale swartz) almacenado 1 a $2{ }^{\circ} \mathrm{C}$. Rev Fac Nac Agr Medellín, 60(2), 4179-4193.

Bao, L., Yao, X. S., He, R. R., \& Kurihara, H. (2008). Protective effects of Guangdong Liangcha grandes on restraint stress-induced liver damage in mice. Journal of Agricultural and Food Chemistry, 33(6), 664-669. PMid:18590196.

Barona, J., Aristizabal, J. C., Blesso, C. N., Volek, J. S., \& Fernandez, M. L. (2012). Grape polyphenols reduce blood pressure and increase flow-mediated vasodilation in men with metabolic syndrome. The Journal of Nutrition, 142(9), 1626-1632. http://dx.doi.org/10.3945/ jn.112.162743. PMid:22810991.

Basu, A., \& Lyons, T. J. (2012). Strawberries, blueberries, and cranberries in the metabolic syndrome: clinical perspectives. Journal of Agricultural and Food Chemistry, 60(23), 5687-5692. http://dx.doi.org/10.1021/ jf203488k. PMid:22082311.

Basu, A., Betts, N. M., Ortiz, J., Simmons, B., Wu, M., \& Lyons, T. J. (2011). Low-energy cranberry juice decreases lipid oxidation and increases plasma antioxidant capacity in women with metabolic syndrome. Nutrition Research (New York, N.Y.), 31(3), 190-196. http://dx.doi.org/10.1016/j.nutres.2011.02.003. PMid:21481712.

Basu, A., Du, M., Leyva, M. J., Sanchez, K., Betts, N. M., Wu, M., Aston, C. E., \& Lyons, T. J. (2010). Blueberries decrease cardiovascular risk factors in obese men and women with metabolic syndrome. The Journal of Nutrition, 140(9), 1582-1587. http://dx.doi.org/10.3945/ jn.110.124701. PMid:20660279.

Benzie, I. F., \& Strain, J. J. (1996). The Ferric Reducing Ability of Plasma (FRAP) as a measure of antioxidant power: the FRAP Assay. Analytical Biochemistry, 239(1), 70-76. http://dx.doi.org/10.1006/ abio.1996.0292. PMid:8660627.

Bravo, K., Sepulveda-Ortega, S., Lara-Guzman, O., Navas-Arboleda, A. A., \& Osorio, E. (2015). Influence of cultivar and ripening time on bioactive compounds and antioxidant properties in Cape gooseberry (Physalis peruviana L.). Journal of the Science of Food and Agriculture, 95(7), 1562-1569. http://dx.doi.org/10.1002/jsfa.6866. PMid:25131258.

Camp, W. (1945). The North American blueberries with notes on other groups of Vacciniaceae. Brittonia, 5(3), 203-275. http://dx.doi. org/10.2307/2804880.

Chrzczanowicz, J., Gawron, A., Zwolinska, A., Graft-Johnson, J., Krajewski, W., Krol, M., Markowski, J., Kostka, T., \& Nowak, D. (2008). Simple method for determining human serum 2, 2-diphenyl-1- picrylhydrazyl (DPPH) radical scavenging activity - possible application in clinical studies on dietary antioxidants. Clinical Chemistry and Laboratory Medicine, 46(3), 342-349. PMid:18254708.

Contreras-Calderón, J., Calderón-Jaimes, L., Guerra-Hernández, E., \& García-Villanova, B. (2011). Antioxidant capacity, phenolic content and vitamin C in pulp, peel and seed from 24 exotic fruits from Colombia. Food Research International, 44(7), 2047-2053. http:// dx.doi.org/10.1016/j.foodres.2010.11.003.

D’Archivio, M., Filesi, C., Di Benedetto, R., Gargiulo, R., Giovannini, C., \& Masella, R. (2007). Polyphenols, dietary sources and bioavailability. Annali dell'Istituto Superiore di Sanita, 43(4), 348-361. PMid:18209268.

Duthie, S. J., Jenkinson, A. M., Crozier, A., Mullen, W., Pirie, L., Kyle, J., Yap, L. S., Christen, P., \& Duthie, G. G. (2006). The effects of cranberry juice consumption on antioxidant status and biomarkers relating to heart disease and cancer in healthy human volunteers. European Journal of Nutrition, 45(2), 113-122. http://dx.doi.org/10.1007/ s00394-005-0572-9. PMid:16032375.

Escobar, L., Alzate, G., Echeverry, A., Villegas, C., Mora, G., \& Ramírez, M. (2009). Conozcamos y usemos el mortiño (3. ed.). Medellín: Corporación Autónoma Regional del Centro de Antioquia.

Ferruzzi, M. G., Lobo, J. K., Janle, E. M., Cooper, B., Simon, J. E., Wu, Q. L., Welch, C., Ho, L., Weaver, C., \& Pasinetti, G. M. (2009). Bioavailability of gallic acid and catechins from grape seed polyphenol extract is improved by repeated dosing in rats: Implications for treatment in Alzheimer's disease. Journal of Alzheimer's Disease, 18(1), 113-124. http://dx.doi.org/10.3233/JAD-2009-1135. PMid:19625746.

Garzón, G. A., Narváez, C. E., Riedl, K. M., \& Schwartz, S. J. (2010). Chemical composition, anthocyanins, non-anthocyanin phenolics and antioxidant activity of wild bilberry (Vaccinium meridionale Swartz) from Colombia. Food Chemistry, 122(4), 980-986. http:// dx.doi.org/10.1016/j.foodchem.2010.03.017.

Gaviria, C., Hernández, J., Lobo, M., Medina, C., \& Rojano, B. (2012). Cambios en la Actividad Antioxidante en Frutos de Mortiño (Vaccinium meridionale Sw.) durante su Desarrollo y Maduración. Revista Univ Nac Fac Agr Medellín, 65(1), 6487-6495.

Gaviria, C., Ochoa, C., Sánchez, N., Medina, C., Lobo, M., Galeano, P. L., Mosquera, A. J., Tamayo, A., Lopera, Y. E., Rojano, B. A., \& Gaviria, C. A. (2009). Propiedades antioxidantes de los frutos de agraz o mortiño (Vaccinium meridionale Swartz). Bogotá: Universidad Nacional de Colombia.

Grace, M. H., Ribnicky, D. M., Kuhn, P., Poulev, A., Logendra, S., Yousef, G. G., Raskin, I., \& Lila, M. A. (2009). Hypoglycemic activity of a novel anthocyanin-rich formulation from lowbush blueberry, Vaccinium angustifolium Aiton. Phytomedicine, 16(5), 406-415. http://dx.doi.org/10.1016/j.phymed.2009.02.018. PMid:19303751.

Grundy, S., Cleeman, J., Daniels, S., Donato, K. A., Eckel, R. H., Franklin, B. A., Gordon, D. J., Krauss, R. M., Savage, P. J., Smith, S. C. Jr, Spertus, J. A., \& Costa, F., (2005). Diagnosis and management of the metabolic syndrome an American Heart Association/National Heart, Lung, and Blood Institute scientific statement. Circulation, 112(17), 2735- 
2752. http://dx.doi.org/10.1161/CIRCULATIONAHA.105.169404. PMid:16157765.

Harasym, J., \& Oledzki, R. (2014). Effect of fruit and vegetable antioxidants on total antioxidant capacity of blood plasma. Nutrition (Burbank, Los Angeles County, Calif.), 30(5), 511-517. http://dx.doi. org/10.1016/j.nut.2013.08.019. PMid:24698344.

Horwitz W, Chichilo P, Reynolds H. (1990). Official methods of analysis of the Association of Official Analytical Chemistry. Arlington: AOAC.

Huang, H., Chen, G., Liao, D., Zhu, Y., \& Xue, X. (2016). Effects of Berries Consumption on Cardiovascular Risk Factors: A Metaanalysis with Trial Sequential Analysis of Randomized Controlled Trials. Scientific Reports, 6(1), 23625. http://dx.doi.org/10.1038/ srep23625. PMid:27006201.

Instituto Colombiano de Normas Técnicas y Certificación - ICONTEC. (2009). Microbiología de alimentos y productos para la alimentación animal. Requisitos generales y directrices para análisis microbiológicos (Norma Técnica Colombiana). NTC 4092. Retrieved from: http:// service.udes.edu.co/modulos/documentos/karenmartinez/50159704NTC4092.pdf

Kuntz, S., Kunz, C., Herrmann, J., Borsch, C. H., Abel, G., Fröhling, B., Dietrich, H., \& Rudloff, S. (2014). Anthocyanins from fruit juices improve the antioxidant status of healthy young female volunteers without affecting anti-inflammatory parameters: results from the randomised, double-blind, placebo-controlled, cross-over ANTHONIA (ANTHOcyanins in Nutrition Investigation Alliance) study. British Journal of Nutrition, 112(6), 925-936. http://dx.doi. org/10.1017/S0007114514001482. PMid:25089359.

Lee, J., Durst, R. W., \& Wrolstad, R. E. (2002). Impact of juice processing on blueberry anthocyanins and polyphenolics: comparison of two pretreatments. Journal of Food Science, 67(5), 1660-1667. http:// dx.doi.org/10.1111/j.1365-2621.2002.tb08701.x.

Ligarreto, G. A. (2009). Descripción del género Vaccinium, estudio de caso: agraz o mortiño (Vaccinium meridionale Swartz) (1. ed.). Medellín: Universidad Nacional de Colombia.

Ligarreto, G. A., Patiño, M. P., \& Magnitskiy, S. V. (2011). Phenotypic plasticity of Vaccinium meridionale (Ericaceae) in wild populations of mountain forests in Colombia. Revista de Biología Tropical, 59(2), 569-583. PMid:21717851.

Lopera, Y. E., Fantinelli, J., Arbeláez, L. F. G., Rojano, B., Ríos, J. L., Schinella, G., \& Mosca, S. (2013). Antioxidant activity and cardioprotective effect of a nonalcoholic extract of Vaccinium meridionale Swartz during ischemia-reperfusion in rats. Evidence-based complementary and alternative medicine : eCAM, 2013, 516727. http://dx.doi. org/10.1155/2013/516727. PMid:23476693.

Maldonado-Celis, M. E., Arango-Varela, S. S., \& Rojano, B. A. (2014). Capacidad atrapadora de radicales libres, efectos citotóxicos y antiproliferativos de Vaccinium meridionale Sw. en líneas celulares de cáncer de colon. Revista Cubana de Plantas Medicinales, 19(2), 172-184.

Manach, C., Scalbert, A., Morand, C., Rémésy, C., \& Jiménez, L. (2004). Polyphenols: food sources and Bioavailability. The American Journal of Clinical Nutrition, 79(5), 727-747. http://dx.doi.org/10.1093/ ajcn/79.5.727. PMid:15113710.

Montoya, C., Ospina, C., Sánchez, N., Medina, C., Lobo, M., Galeano, P., Martínez, A. M., Tenorio, A. T., Pérez, Y. L., \& Rojano, B. (2009). Actividad antioxidante e inhibición de la peroxidación lipídica de extractos de frutos de mortiño (Vaccinium meridionale SW). Boletín Latinoamericano y del Caribe de Plantas Medicinales y Aromáticas, 8(6), 519-528.
Nile, S. H., \& Park, S. W. (2014). Edible berries: review on bioactive components and their effect on human health. Nutrition (Burbank, Los Angeles County, Calif.), 30(2), 134-144. PMid:24012283.

Nurhuda, H. H., Maskat, M. Y., Mamot, S., Afiq, J., \& Aminah, A. (2013). Effect of blanching on enzyme and antioxidant activities of rambutan (nephelium lappaceum) peel. International Food Research Journal, 20(4), 1725-1730.

Ou, B., Hampsch-Woodill, M., \& Prior, R. L. (2001). Development and validation of an improved oxygen radical absorbance capacity assay using fluorescein as the fluorescent probe. Journal of Agricultural and Food Chemistry, 49(10), 4619-4626. http://dx.doi.org/10.1021/ jf010586o. PMid:11599998.

Pedersen, C. B., Kyle, J., Jenkinson, A. M., Gardner, P. T., McPhail, D. B., \& Duthie, G. G. (2000). Effects of blueberry and cranberry juice consumption on the plasma antioxidant capacity of healthy female volunteers. European Journal of Clinical Nutrition, 54(5), 405-408. http://dx.doi.org/10.1038/sj.ejcn.1600972. PMid:10822287.

Pérez-Jiménez, J., Neveu, V., Vos, F., \& Scalbert, A. (2010). Identification of the 100 richest dietary sources of polyphenols: an application of the Phenol-Explorer database. European Journal of Clinical Nutrition, 64(Suppl. 3), S112-S120. http://dx.doi.org/10.1038/ejcn.2010.221. PMid:21045839.

Pertuzatti, P. B., Barcia, M. T., Rodrigues, D., Cruz, P. N., HermosínGutiérrez, I., Smith, R., \& Godoy, H. T. (2014). Antioxidant activity of hydrophilic and lipophilic extracts of Brazilian blueberries. Food Chemistry, 164, 81-88. http://dx.doi.org/10.1016/j.foodchem.2014.04.114. PMid:24996309.

Prior, R. L., Gu, L., Wu, X., Jacob, R. A., Sotoudeh, G., Kader, A. A., \& Cook, R. A. (2007). Plasma antioxidant capacity changes following a meal as a measure of the ability of a food to alter in vivo antioxidant status. Journal of the American College of Nutrition, 26(2), 170-181. http://dx.doi.org/10.1080/07315724.2007.10719599. PMid:17536129.

Prymont-Przyminska, A., Bialasiewicz, P., Zwolinska, A., Sarniak, A., Wlodarczyk, A., Markowski, J., Rutkowski, K. P., \& Nowak, D. (2016). Addition of strawberries to the usual diet increases postprandial but not fasting non-urate plasma antioxidant activity in healthy subjects. Journal of Clinical Biochemistry and Nutrition, 59(3), 191-198. PMid:27895386.

Santo-Buelga, C., Escribano-Bailon, M. T., \& Lattanzio, V. (2010). Recent advances in polyphenol research (2nd ed.). United Kingdom: John Wiley \& Sons.

Serafini, M., Maiani, G., \& Ferro-luzzi, A. (1998). Alcohol-free red wine enhances plasma antioxidant capacity in humans. The Journal of Nutrition, 128(6), 1003-1007. http://dx.doi.org/10.1093/jn/128.6.1003. PMid:9614160.

Shen, M., Li, K., Jing, H., \& Zheng, L. (2018). In vivo therapeutic effect of vaccinium meridionale swartz in ischemia-reperfusion induced male albino rats. Journal of Food Science, 83(1), 221-228. http:// dx.doi.org/10.1111/1750-3841.13986. PMid:29178435.

Skrede, G., Wrolstad, R. E., \& Durst, R. W. (2000). Changes in anthocyanins and polyphenolics during juice processing of highbush blueberries (Vaccinium corymbosum L.). Journal of Food Science, 65(2), 357-364. http://dx.doi.org/10.1111/j.1365-2621.2000.tb16007.x.

Swain, T., \& Hillis, W. E. (1959). The phenolic constituents of Prunus domestica. I. - The quantitative analysis of phenolic constituents. Journal of the Science of Food and Agriculture, 10(1), 63-68. http:// dx.doi.org/10.1002/jsfa.2740100110.

Tobón, Y. N. F., Rojano, B., Arbeláez, A. F. A., Florez, C. E. R., Barrios, D. M. R., \& Celis, M. E. M. (2016). Efecto del tiempo de almacenamiento 
sobre propiedades fisicoquímicas y antioxidantes de productos derivados del fruto agraz (Vaccinium meridionale swartz). Vitae, 23(3), 184-193. http://dx.doi.org/10.17533/udea.vitae.v23n3a04.

Vahos, I. C. Z., Ochoa, S., Maldonado, M., Zapata, A., \& Rojano, B. (2016). Cytotoxic effect and antioxidant activity of Andean berry (Vaccinium meridionale Sw) wine. Journal of Medicinal Plants Research, 10(27), 402-408. http://dx.doi.org/10.5897/JMPR2016.6100.

van het Hof, K. H., Wiseman, S. A., Yang, C. S., \& Tijburg, L. B. (1999). Plasma and lipoprotein levels of tea catechins following repeated tea consumption. Proceedings of the Society for Experimental Biology and Medicine, 220(4), 203-209. http://dx.doi.org/10.1046/j.1525-1373.1999. d01-34.x. PMid:10202389.
Yao, N., Lan, F., He, R. R., \& Kurihara, H. (2010). Protective effects of bilberry (Vaccinium myrtillus L.) extract against endotoxin-induced uveitis in mice. Journal of Agricultural and Food Chemistry, 58(8), 4731-4736. http://dx.doi.org/10.1021/jf904572a. PMid:20222750.

Zhao, C., Giusti, M. M., Malik, M., Moyer, M. P., \& Magnuson, B. A. (2004). Effects of commercial anthocyanin-rich extracts on colonic cancer and nontumorigenic colonic cell growth. Journal of Agricultural and Food Chemistry, 52(20), 6122-6128. http://dx.doi. org/10.1021/jf049517a. PMid:15453676.

Zielinska, M., Sadowski, P., \& Blaszczak, W. (2015). Freezing/thawing and microwave-assisted drying of blueberries (Vaccinium corymbosum L.). Lebensmittel-Wissenschaft + Technologie, 62(1), 555-563. http:// dx.doi.org/10.1016/j.lwt.2014.08.002. 